\title{
The Security Sector, the Budget and Development
}

\author{
Nicole Ball
}

\section{Introduction}

Surveys of the state of the world economy in the early 1980 s have painted a sombre picture of conditions in the Third World. In many developing countries, output has stagnated since the late 1970s, and the economic recovery experienced by the industrialised countries to date has been insufficient to spur widespread economic growth. The World Bank reported that the terms of trade faced by most developing countries in 1982 were the worst in the post-World War II period, while the United Nations predicted that in many countries, per capita income would continue its decline [World Bank 1984: 26; UN 1983: 1-8].

Although the situation confronting the Third World has become particularly disadvantageous since the end of the $1970 \mathrm{~s}$, the failure of many Third World governments to set their countries on a path of selfsustaining economic growth has been evident for a long time. A number of reasons for this failure have been advanced, including inequality within and among countries, adverse global economic conditions and waste of resources. Some analysts believe that expenditure on the security sector is an important factor. ${ }^{I}$ They argue that if security expenditures could be reduced and the resources thus released could be invested productively, economic growth and development would be promoted.

In determining which factors perpetuate underdevelopment, it is clearly necessary to consider both internal and external conditions. No one factor or group of factors can be considered a sufficient explanation. Hence reducing expenditure on the security sector will not by itself alter economic development prospects significantly. Taken in con-

\footnotetext{
$\bar{i}$ In this article, the terms "security sector' and 'security expenditure" are employed in preference to the more commonly used 'military sector' and 'military expenditure' to indicate the inclusion of paramilitary forces in the discussion. This usage also reflects the fact that Third World governments frequently use their armed forces to maintain themselves in power, that is, to promote regime security.
}

junction with other changes, however, it may have a much more significant impact.

\section{The Data Problem}

The first problem in assessing how reduced security expenditure can contribute to economic development is the lack of reliable data. Data on a wide variety of economic and social conditions in developing countries are often difficult to come by, and security expenditure is no exception. How much of its resources a country devotes to security-related activities is often considered sensitive, and is therefore cloaked with secrecy. One reason why governments are reluctant to discuss their security outlays openly is to prevent potential opponents from knowing too much about their military establishments. At the same time, however, the secrecy with which governments surround security issues is often designed to prevent their own citizens from learning too much about them. But not all developing countries attempt to obscure their security spending, nor are they the only ones to do so. Eastern-bloc countries also provide extremely limited information on their security outlays.

Nonetheless, there are a number of sources that provide information on the military-related component of government, for a broad spectrum of countries. The best known annual publications are the US Arms Control and Disarmament Agency's (ACDA), World Military Expenditures and Arms Transfers, the Stockholm International Peace Research Institute's (SIPRI) World Armaments and Disarmament: SIPRI Yearbook, the International Monetary Fund's Government Finance Statistics Yearbook and the International Institute of Strategic Studies' (IISS) The Military Balance. In addition, many Third World countries publish their own data in budget estimates and final expenditure accounts. Data published by national governments are, however, frequently considered suspect, as researchers and other analysts assume that governments conceal large portions of their security budgets from public scrutiny. While it is 
true that concealment occurs, on quite a large scale in some cases, it is wrong to assume that the data provided in the international sources mentioned above are any more reliable, since the organisations which are responsible for these publications receive their information directly or indirectly from national governments.

There is often considerable variation among these sources, due in part to the different definitions of security expenditure adopted by individual national governments and the various organisations which collect security expenditure data. The IISS has no definition and accepts whatever figure national sources provide. While ACDA and SIPRI have their own definitions of what constitutes security expenditure, in practice these two organisations do little more than reproduce data provided in one form or another by governments. Both increasingly use the IMF as the source of the data they publish, because the IMF definition is the most inclusive, IMF members being supposed to take it into account when supplying budget information to the Fund.

The definitional question is not trivial, [see Ball 1984: 1-15] since security expenditure can easily be listed in national budgets under civilian ministries. In Iran, for example, expenditure on the paramilitary Gendarmerie has sometimes been included under the Ministry of Defence and sometimes under the Ministry of the Interior. For the IMF, this should not have posed a problem, since the Iranian government ought to have reported expenditure on the Gendarmerie irrespective of where it was listed in the budget. Any other source which has simply reported the figures listed under Ministry of Defence will produce an expenditure series which has serious internal inconsistencies. Conversely, not all expenditure listed in the defence budgets of developing countries is defence-related. In Saudi Arabia and Pakistan, for example, civil aviation is funded through the Ministry of Defence.

The data produced by the IMF are probably the most consistent and comparable of the data collected by the four organisations mentioned above. It must be realised, however, that this is no guarantee of their accuracy because governments often fail to report portions of their security budgets to the fund. ${ }^{2}$ The

\footnotetext{
2 Just how inaccurate IMF data are is a matter of some debate. In a recently published book on Africa, an IMF official was quoted as stating that it is virtually impossible to assess the financial impact of military expenditures on development because most funding is done outside nornal channels, is considered off the books, and is therefore never madc available to the IMF. More often than not, when the issue is pressed. figures are fabricated or reflect only domestic military expenditures, not imports, so as 10 support requests for balance-of-payments support from the fund [Arlinghaus 1984: 577. The IMF official with whom I have spoken was not so categoricat. Emphasis was laid on the difficulty in tracking down procurement payments, which are often lumped logether with other debts in budgets or are made off-budget.
}

potential divergencies between the reporting of Third World security expenditure by various sources can be illustrated by comparing the Guyanese government's figures for its security outlays in the period 1967-79 with data published by ACDA, the IMF and SIPRI. (Guyana is chosen because it is one of the few developing countries which provides breakdowns of its actual outlays.) The ACDA figures clearly correspond to the operating costs of the military forces shown in the Guyanese figures rounded to the nearest million, with the exception of 1979 . This raises two problems. The figure for 1978 is not for actual expenditure, but for revised estimates. More serious, ACDA data omit capital costs for all years and are thus only partial expenditure figures. The IMF data are also partial, because between 1967 and 1973 and in 1978 the IMF appears to have reported total outlays on military forces only, even though its definition of security expenditure includes outlays on paramilitary forces. The Guyanese Police Force has paramilitary duties, and expenditure on them should therefore have been included. SIPRI, which generally does not include paramilitary spending in its data, appears to have reported expenditure on both the armed forces and the police force in 1973. Thus, as these figures from Guyana illustrate, while in many cases national budgets do not reveal the entire extent of security spending, they are sometimes more accurate than the estimates produced by international bodies.

Many governments attempt to hide portions of their security expenditure, for example by publishing only one figure for security spending (these include Pakistan, Botswana and Bangladesh), by trading commodities directly for weapons to reduce procurement costs in the budget (India), and by building up extra-budgetary funds to finance a variety of securityrelated outlays (Indonesia, Ecuador) [Ball 1984: 15-19]. At the same time, it is important to realise that different estimates of a country's security expenditure can arise without the government necessarily trying to hide portions of its expenditure. For instance, there can be genuine differences of opinion as to whether a given item of expenditure should be categorised as security related, as in different kinds of police expenditure.

The way in which budgets are organised can also produce problems. Not only are paramilitary forces often to be found in the budget of the Interior Ministry, but military-related construction is sometimes listed under departments of public works, military pensions can be listed with state pensions for civilian employees, and loans incurred to purchase weapons are frequently listed under debt repayment. Without access to a detailed government budget or final expenditure account, a person compiling security 
expenditure figures runs a serious risk of producing inaccurate and inconsistent data.

Nonetheless, budgets do not always reveal everything, and the most serious problems in measuring security expenditure still arise from the desire of governments for concealment. In such situations, a detailed knowledge of the country concerned and of what the security sector says it is spending its money on, can help to produce somewhat more accurate estimates of the size of security budgets. In Nicaragua in the late 1970 s, for example, when the Somoza government was intensifying its military activities against the Sandinistas, the Nicaraguan security budget showed a surprisingly low level of outlays on weapons and ammunition [Ball 1984: 228-9]. The suspicion thus inevitably arises that, even though the Nicaraguan security budget nearly doubled between 1976 and 1978 , some portions of security-related outlays were concealed by the government. In Ecuador, it is widely believed that the armed forces have the right to dispose of 15 per cent of the country's annual income from the petroleum industry. This money is additional to the yearly allocation to the armed forces made through the state budget. India is known to exchange certain commodities and manufactures for Soviet weapons. These transactions are recorded in as little detail as possible in the balance of trade and are never entered into the Indian budget. In spite of this, however, the Indian security budget provides a good indication of where the bulk of Indian security expenditure goes. ${ }^{3}$

\section{Security Expenditure - the Implications for Disarmament and Development}

None of the major international series of security expenditure figures has ever attempted to produce disaggregated data. Nevertheless, more detailed information on security spending has long been recognised as a prerequisite for successful negotiations on military expenditure reductions [UN Centre for Disarmament 1981: 1, para. 5]. The United Nations has called for the collection of disaggregated security expenditure data, both through the UN Expert Group on the Relationship between Disarmament and Development and through the work of the Ad Hoc Panel on Military Budgeting. Nevertheless, the Soviet Union has succeeded in blocking the recommendation of the UN Expert Group for information broken down 'in terms of personnel, administration, procurement, research and development, capital investment'. ${ }^{4}$

\footnotetext{
3 Indian security expenditure is list ed in several portions of the state budget. An extremely detailed account of by far the largest share of the security budget is published annually in Government of India. Defence Services Estimates. Other portions of security spending can be found in Combined Finance and Revenus Accounts of the Central and State Governments in India and Explanatory Memorandum of the Central Government.

${ }^{4}$ Note transmilted to the Secretary-General from the Group of Governmental Experts on the Relaionship between Disarmament and Developmem, Geneva: 26 January 1979, see Annex, p.l.
}

The work of the Ad Hoc Panel has, however, been institutionalised. Each year the United Nations requests Member Governments to submit information on their security expenditures disaggregated according to a matrix devised by the Panel in the late 1970 s [reproduced in UN 1981:32-4]. To date, this effort has not been notably successful as a means of collecting information. Just over 30 countries have replied during the five years that the reporting mechanism has been in place. No Eastern-bloc country has ever participated, and very few developing countries have made information available. Nonetheless, this exercise is valuable. If governments become accustomed to reporting their security outlays on an annual basis, this could be a first, albeit small, step toward serious consideration of the need to place limitations on security spending.

Although only a few Third World countries report their security expenditures to the UN, the information regularly published by governments in their own budget documents brings out a number of facts relevant to the discussion of disarmament and development. For most people, Third World security expenditure is synonymous with expenditure on weapons and related services. One often hears researchers, government officials and international civil servants speak of 'arms spending' instead of 'military expenditure'. Most developing countries, however, allocate surprisingly small amounts of their security budgets to arms procurement. Operating costs (personnel costs plus operations and maintenance outlays) have always absorbed the largest portion of Third World security spending. An examination of 20 developing countries between $195 \mathrm{I}$ and 1979 indicates that operating costs commonly account for 70-90 per cent of total security, with personnel costs alone typically absorbing between 50 and 70 per cent of the entire security budget. ${ }^{5}$ Even if one were to assume under-reporting of procurement budgets by as much as 100 per cent, the proportion of their security spending most countries devote to purchasing arms would still be very small.

This finding is reinforced by a close examination of arms trade statistics. ${ }^{6}$ While it is well known that the volume and value of the arms trade increased significantly during the $1970 \mathrm{~s}$, this trade was heavily concentrated in a few countries. According to figures produced by the US Arms Control and Disarmament Agency, 8 countries received more than half of all

\footnotetext{
5 The data on operating costs are available in Ball 1984 and the data on personnel costs are from the author's files. The 20 countries are: India*. Iran, Malaysia*., Pakistan. Philippines*, Sri Lanka*. Ghana, Liberia*. Malagasy Republic*. Morocco. Nigeria, Sierra Leone, Argentina. Brazil*. Chile. Colombia. Guyana*. Nicaragua, Trinidad and Tobago*, Venezueta*. An asterisk indicates that information on personnel costs was available.
} 
weapons transferred to the Third World during the 1970 s, while 20 countries accounted for nearly threequarters of the arms transferred. Approximately 90 developing countries imported about the same value of weapons during the $1970 \mathrm{~s}$ as just three countries, namely Iran, Iraq and Syria.

This does not mean that the purchase of a small amount of weapons cannot absorb a large portion of a country's security budget. It does, however, make it less likely that all developing countries regularly spend most of their security budgets on arms. Even some of the major arms importers, for example India, Brazil and Cuba, spend very little of their security-related resources on arms procurement. Cuba is said to receive all of its weapons free of charge from the Soviet Union. As explained above, India does not record all its arms deals in its budget. However, even if it were assumed that Indian security budgets understate arms procurement by 100 per cent each year, the proportion of Indian security spending absorbed by weapon procurement (including expenditures on the domestic arms industry) would have averaged between 10 and 15 per cent during the 1960s and 1970s. For Brazil the figure would perhaps be 10 per cent.

This pattern of expenditure reflects the fact that in most countries the primary use of the security forces is a domestic, political one. Underdevelopment is closely associated with inequalities among and within countries. Throughout the Third World, security forces have become important both as mediators between different elite groups and as guarantors of elite-dominated political systems. The concentration of political and economic power in the hands of a small elite is an open invitation for the few, distinguished by characteristics such as class, ethnicity, religion and occupation, to exploit the many. The resultant discontent causes governments to arm themselves against their own people.

\footnotetext{
${ }^{6}$ Arms transfer statistics are just as problematic as military expenditure figures. if not more so. Furthermore. there are no national figures with which to compare them. since trade and balance of payments accounts do not categorise weapons imports separately. Estimates of arms exports by the arms exporting countries are of variable quality and do not always correspond with the estimates made by ACDA and SIPRI. ACDA arms transfer data do not reflect the entire value of arms transfers since. in addition to what may inadvertently be excluded. ACDA omits the costs of military-related construction. training and technical services. These may be equivalent to some 15 per cent of total arms transferred. SIPRI arms transfer data are even less inclusive. since they cover only major weapons. In addition. neither ACDA nor SIPRI data can be taken as an indication of what the weapons imported actually cost the recipient, since prices and terms of financing will vary according to the political relationship between supplier and purchaser. Some arms are transferred free-of-charge. with the cost being absorbed by the supplier or by a third party (for example. Saudi Arabia). Both ACDA and SIPRI data can. however. be used to indicate trends. The accuracy and limitations of arms transfer figures are discussed in Brzoska 1982: 77-108.
}

The preponderance of operating costs and the domestic political orientation of most security forces suggests that it will be difficult to produce large reductions in the level of security expenditure in the Third World simply by imposing limitations on the arms trade and by encouraging the peaceful resolution of interstate conflicts, the two areas on which efforts at the international level to reduce security spending tend to concentrate. This is not to say that such proposals are not in themselves desirable. On the contrary, fewer conflicts would give the major powers less opportunity to intervene in the affairs of developing countries. This might result in lower security expenditure on the part of the major powers and could reduce the external threats confronting Third World governments, hopefully encouraging some of them to reduce their security budgets. But unless domestic inequalities can also be greatly reduced, sustained reductions in security spending are unlikely.

The same factors also suggest that the development dividends that can be anticipated from disarmament may be initially rather small. It is clear that even a large reduction in the procurement of weapons would leave a very large proportion of Third World security budgets untouched and would not produce sizeable savings that could be translated into productive investment. This is especially true when arms purchases are financed by supplier or third-party credits, since these credits would most likely not be transferrable to the civil sector.

Similarly, fewer interstate wars would by no means reduce the incentive to maintain security forces. This is quite clearly demonstrated by South America where there have been few active conflicts among countries during the last century, but where security spending continues to flourish. It can surely be no accident that the concept of 'national security', which legitimises the domestic role of the armed forces, was devised in South America. (The Indonesian dwi fungsi (dual function) doctrine and the Burmese 'National Ideology of the Defence Services' were developed at about the same time, but, as far as is known, independently.)

It is crucial, however, that development analysts and practitioners begin to take into account the economic and political effects of security expenditure. In some countries, the short-term economic costs of security spending are important. The allocation of resources to the security sector can contribute to high rates of inflation, high levels of indebtedness, urban bias and unfavourable trade balances. In other countries, the economic effects are negligible. Hence it is important to differentiate between countries and among timeperiods. Moreover the political effects of security spending - which influence the longer-term evolution 
of the economy - are usually negative. In situations characterised by a high degree of political and economic inequality, the main effect of security spending is to strengthen the security forces at the expense of other groups in society. The greater the political power of the security forces, the more difficult it is to effect change not approved by them. Most security forces support the continuation of elitedominated systems rather than their replacement by more participatory forms of government, because they believe they stand to gain more, both personally and professionally, from the former. The perpetuation of elite-dominated systems reduces the likelihood that political systems responsive to the needs of all citizens - and not just a small proportion of them - will ever be created. This situation can be changed with sufficient pressure from the mass of the population, but only over the long term and not if the armed forces constantly intervene.

However, even if security expenditure were to decline sharply, the security sector were to be substantially reduced in size, and the armed forces were to leave the political arena, this would not by itself guarantee development. There are too many examples of inefficient, corrupt, and uninterested civilian govern- ments in the Third World to warrant such an optimistic conclusion. Yet the removal of the armed forces from politics is a necessary first step.

\section{References}

Arlinghaus, Bruce E., 1984, Military Development in Africa: The Political and Economic Risks of Arms Transfers, Westview Press, Boulder $(\mathrm{Co})$ and London

Ball, Nicole, 1984, Third World Security Expenditure: A Statistical Compendium, FOA Report C 10250 - M5, National Defence Research Institute, Stockholm, May

Brzoska, Michael. 1982, 'Arms transfer data sources', Journal of Conflict Resolution vol 26 no 1, March

United Nations, 1983, World Economic Survey, 1983: Current Trends and Policies in the World Economy, Department of International Economic and Social Affairs, E/1983/42, ST/ESA/131

United Nations Centre for Disarmament, 1981, Reductions of Military Budgets: International Reporting of Military Expenditures, Study Series 4, UN, New York

World Bank, 1984, World Development Report, Oxford University Press 